\title{
Acacia hydaspica ethyl acetate extract protects against cisplatin-induced DNA damage, oxidative stress and testicular injuries in adult male rats
}

\author{
Tayyaba Afsar ${ }^{1}$, Suhail Razak ${ }^{2,3^{*}}$, Muhammad Rashid khan ${ }^{1}$ and Ali Almajwal ${ }^{3}$
}

\begin{abstract}
Background: Cisplatin (CP), an effective anticancer agent, carries the risk of impairing testicular function leading to infertility. The present study aimed at evaluating the protective effect of A. hydaspica ethyl acetate extract (AHE) against CP-induced oxidative stress and testicular injuries in rats.

Methods: Rats were divided into six groups $(n=6)$. Group I (control), group II (CP single dose on day 16). Group III received AHE for 21 days. Group IV (CP + AHE; post- treatment group). Group V (AHE + CP; pre-treatment group) and group VI (CP + Sily).

Results: CP treatment reduced serum testosterone (T), LH and FSH, decreased the activity level of antioxidant enzymes while increased the concentration of oxidative stress markers, i.e. thiobarbituric acid reactive substances (TBARS), $\mathrm{H}_{2} \mathrm{O}_{2}$ and nitric oxide (NO) along with corresponding DNA damages. Furthermore, $\mathrm{CP}$ induced adverse morphological changes in testis of rats including reduced epithelial height and tubular diameter, increased luminal diameter with impaired spermatogenesis. Pre and post-treatment with AHE reduced the side effects of CP in testis tissues through improvement in the reproductive hormonal secretions, enzymatic activities, histological and DNA damage parameters. Pretreatment seems to be more effective and equivalent to silymarin group in reversing the $\mathrm{CP}$ deleterious effects as compared to post-treatment.

Conclusion: The results demonstrated that A. hydaspica treatment in CP-induced testicular toxicity augments the antioxidants defense mechanism, reverted the level of fertility hormones, suppressed the histomorphological alterations and DNA damages and thus provides the evidence that it may have a therapeutic role in free radical mediated diseases.
\end{abstract}

Keywords: Cisplatin, Testicular impairment, Antioxidant enzymes, Reproductive hormones, DNA damages

\section{Background}

Cisplatin (CP) is a platinum-derived anti-neoplastic, DNA alkylating agent used widely as a front line adjuvant therapy against various cancers such as testicular, gut, stomach, head, neck, ovarian, cervical, germ cell tumors and non-small cell lung carcinoma [1]. Use of CP in the treatment of testicular cancer, even at the progressive stage of

\footnotetext{
* Correspondence: ruhail12345@yahoo.com

2Department of Animal Sciences, Quaid-i-Azam University, Islamabad, Pakistan

${ }^{3}$ Department of Community Health Sciences, College of Applied Medical Sciences, King Saud University, Riyadh, KSA, Saudi Arabia

Full list of author information is available at the end of the article
}

the disease has promising results, however, unwanted secondary effects are associated with its use causing reduction of testicular weight, azoospermia and transient or persistent demolition of male reproductive proficiency [2-4]. Spermatogenesis is an intricate phenomenon which is greatly inveigle by the hormonal level and environmental conditions most notably the temperature. This phenomenon implicates multitude of testicular cells such as sertoli cells, Leydig cells and peritubular cells $[5,6]$. Synthesis of nucleic acid in germ cells especially in spermatogonia is impeded by CP treatment on account of its alkylating abilities [7-9]. Damages induced 
with CP to Leydig cells resulted in inhibition of testosterone secretion [10].

Pathogenesis of reproductive impairments ensuing to $\mathrm{CP}$ exposure is usually attributed by the oxidative stress expedited in deterioration of antioxidant defense system. Within the human body protection against oxidative stress is achieved by self-defense enzymes that catalytically remove the free radicals and other reactive species. These include; superoxide dismutase, catalase and glutathione peroxidase [11], whereas $\mathrm{CP}$ decreases the functioning of these enzymes, thereby inducing oxidative damages in testicular tissue $[12,13]$. Current chemotherapeutic agents are mostly non-selective in their efficacy and kill dividing cells rapidly including cancer, normal and stem cells. Such injurious agents also effect spermatogenic cells and fallouts in men infertility [14]. There are cumulative evidences proposing that utilization of antioxidants could be persuasive in ameliorating cisplatin-prompted toxicity [15-17]. Hence there is a necessity to develop combinatorial therapies that will reduce the $\mathrm{CP}$ resistance and minimizing its side effects. Plants possess a wide range of constituents which are capable of preventing various oxidative stress related ailments, including male reproductive disorders [18], hence frequently administered in recipes with chemotherapeutic drugs to give enhanced protection against their side effects [19].

Various species from the genus Acacia exhibit outstanding antioxidant and chemo-preventive possessions that aid in inhibition and treatment of various oxidative stress related ailments [20-22]. Acacia hydaspica R. Parker; synonym $A$. eburnea belongs to family Leguminosae [23]. A. hydaspica possesses antioxidant, anticancer, anti-hemolytic, anti-inflammatory, antipyretic and analgesic potentials; these activities attributed to the presence of various active secondary metabolites i.e. gallic acid, catechin, rutin, caffeic acid, 7-O-galloyl catechin, +catechin and methyl gallate [24]. Polyphenolic compounds isolated from A. hydaspica induce apoptosis and inhibit various pro-survival signaling pathways in breast and prostate cancer cell lines, indicating their potential in molecular target based adjuvant chemotherapy [25]. Ethyl acetate extract of A. hydaspica (AHE) was selected for the in vivo investigation due to its significant antioxidant capacity [26], and the presence of catechin and gallic acid as chief component, substantial total phenolic and flavonoid content (Table 1).

Previous researches indicated that catechins possess persuasive antioxidant, anti-inflammatory, immunomodulatory, and anticancer potential [27]. Similarly epigallocatechin gallate (EG) provided significant protection against testicular toxicity and spermiotoxicity in rats exposed to cisplatin. This is attributed to the beneficial properties of EG, such as inhibition of oxidant/nitrative stress, inflammation, and apoptosis [28]. Silymarin, a natural polyphenolic flavonoid, is extracted from the seeds of Silybum marianum. This flavonoid is known as a potent antioxidant which exerts its protective role in oxidative stress induced disorders [29, 30]. Moreover,silymarin treatment afford protection against antineoplastic drug induced testicular toxicity by maintaining sperm count, testicular spermatid head concentration, daily sperm production, serum testosterone levels and normal spermatogenesis [31]. Therefore, it has become requisite to supplement with antioxidants to minimize the toxicity caused by anti-cancer medications.

Based on earlier research on the protective efficacy of polyphenolic compounds against drug induce reproductive toxicity in animal models and antioxidant properties of A. hydaspica; current experiment was designed to determine the potential of ethyl-acetate extract of $A$. hydaspica to attenuate CP-induced testicular toxicity and oxidative stress in rats. Silymarin was choisen as standard plant derived protective agent for reference. Comet assay and the activity level of various antioxidant enzymes of testicular tissues, histopathological evaluation along with biochemical and hormone analysis of serum was performed to evaluate the protective potential of A. hydaspica against cisplatin induced testicular damages.

\section{Methods \\ Plant collection}

The aerial parts (bark, twigs, and leaves) of A. hydaspica were collected from Kirpa charah area Islamabad, Pakistan. Plant specimen was identified by Dr. Sumaira

Table 1 TPC, TFC, and chemical constituents of A. hydaspica ethyl acetate extract (AHE)

\begin{tabular}{|c|c|c|}
\hline Analysis (AHE fraction) & Observations & (References) \\
\hline TPC (mg gallic acid equivalent/g dry sample) & $120.3 \pm 1.15$ & {$[25]$} \\
\hline TFC (mg rutin equivalent/g dry sample) & $129 \pm 1.32$ & {$[25]$} \\
\hline $\begin{array}{l}\text { HPLC-DAD (Identification of compounds using } \\
\text { standard polyphenolics) }\end{array}$ & $\begin{array}{l}\text { i. Gallic acid ( } 275 \mathrm{~nm}, \mathrm{RT}: 4.516,52.92 \mu \mathrm{g} / 100 \mathrm{mg} \text { dry powder) } \\
\text { ii. Catechin ( } 279 \mathrm{~nm} \text {, RT } 11.427,8648 \mu \mathrm{g} / 100 \mathrm{mg} \text { dry powder) } \\
\text { iii. Myricetin ( } 368 \mathrm{~nm}, \mathrm{RT}: 17.082,34.60 \mu \mathrm{g} / 100 \mathrm{mg} \text { dry powder) }\end{array}$ & {$[25]$} \\
\hline $\begin{array}{l}\text { Purified compounds (identified by NMR } \\
\text { characterization of compounds) }\end{array}$ & $\begin{array}{l}\text { i. 7-O-galloyl catechin }(\mathrm{GC})(187.5 \mathrm{mg} / \mathrm{g}) \\
\text { ii. Catechin (C), }(100 \mathrm{mg} / \mathrm{g}) \\
\text { iii. Methyl gallate }(\mathrm{MG}),(37.5 \mathrm{mg} / \mathrm{g})\end{array}$ & {$[24,27]$} \\
\hline
\end{tabular}


Sahreen (curator at Herbarium of Pakistan, Museum of Natural History, Islamabad). A voucher specimen with Accession No. 0642531 was deposited at the Herbarium of Pakistan, Museum of Natural History, Islamabad for future reference.

\section{Drug and plant dose preparation}

Cisplatin (CP) injection (Sigma-Aldrich, St. Louis, MO, U.S.A.) was dissolved in saline and $7.5 \mathrm{mg} / \mathrm{kg}$ body weight dose of CP was selected on the basis of previous literature to induce testicular toxicity [32]. A. hydaspica methanol extract was fractionated as previously described [33], and its ethyl acetate extract (AHE) (the most bioactive extract under in vitro examinations and containing bioactive polyphenols [34] was selected for further in vivo investigation. Silymarin (100 mg/kg b.w) and AHE (400 mg/kg b.w) were freshly prepared in distilled water before dosing. The dose of extract was selected based on our pilot experiment.

\section{Animals}

Male Sprague Dawley rats (200-225 g) were kept in the Primate Facility at Quaid-i-Azam University, Islamabad. The animals were placed at room temperature, fed with standard pellet diet and tap water under $12 \mathrm{~h}$ light/dark cycle at $25 \pm 3{ }^{\circ} \mathrm{C}$. Guidelines of national institute of animal health (NIH guidelines) were strictly adapted for experimentations. The ethical board of Quaid-i-Azam University, Islamabad permitted the experimental protocol (Bch\#264).

\section{Acute toxicity evaluation}

The acute toxicity study was conducted as per the guidelines 425 of Organization for Economic Cooperation and Development (OECD) for testing of chemicals for acute oral toxicity [35]. Male Sprague Dawley rats were kept in fasting conditions for overnight with just water availability. Three animals were orally administered with dose-of $50 \mathrm{mg} / \mathrm{kg}$ bw and were monitored for mortality rate for $72 \mathrm{~h}$. No initial progression of toxicity was observed, but the methodology was subsequently followed with augmented amount of oral doses i.e., 100, 200, 400, 1000, 2000, 3000 and $4000 \mathrm{mg} / \mathrm{kg}$ bw of AHE, while the control group received saline $(10 \mathrm{ml} / \mathrm{kg})$. Three animals were used for each treatment. General behavioral changes were detected by the previously described procedure [36]. Animals were observed continuously for $2 \mathrm{~h}$ and parameters which were observed were convulsion, tremor, aggression, excitation, loss of grasp, altered reactivity to touch, and sedation [37]. AHE was found to be safe at all tested doses (up to $4000 \mathrm{mg} / \mathrm{kg} \mathrm{b.w)}$ ) and it did not induced any noxious symptom in rats like sedation, convulsions, diarrhea and irritation. $400 \mathrm{mg} / \mathrm{kg}$ bw dose was selected for further in vivo evaluation.

\section{Experimental design}

The experimental plan was designed according to previous studies [38, 39] with minor modifications. Figure 1 summarized the experimental plane. Animals were distributed into six groups $(n=6)$, except the CP group $(n=10)$ due to risk of mortality.

The following treatment procedure was adopted for the study.

Group I: Control received water for 21 days, and saline injection ( $2 \mathrm{ml} / \mathrm{kg}$, i.p) on day 16 .

Group II: CP treated; received one dose of CP (7.5 mg/ $\mathrm{kg}$ b.w., i.p.) on day 16th of experiment for inducing organ toxicity, and distilled water for 21 days (oral).

Group III: AHE treated; $400 \mathrm{mg} / \mathrm{kg}$ body weight/day oral dose for 21 days.

Group IV: CP + AHE (post treated group); CP on day 16 after continuous administration of oral distilled water and AHE (400 mg/kg b.w/day, p.o.) was administered from day 16 to 21 .

Group V: AHE + CP (pretreated group); received $400 \mathrm{mg} / \mathrm{kg}$ body weight/day, p.o. for 21 days and CP (7.5 mg/kg b.w., i.p.) on day 16.

Group VI: Silymarin + CP; received $100 \mathrm{mg} / \mathrm{kg}$ b.w., p.o. dose every other day (11 doses/21 days) and CP (7.5 mg/kg b.w., i.p.) on day 16 .

Initial and final body weights of rats were recorded. Rats were secrified by cervical dislocation after final dosing. Trunk blood was taken with 23 G1 syringes and collected in sterile falcon tubes. Blood was centrifuged at $500 \times \mathrm{g}$ for $15 \mathrm{~min}$ at $4{ }^{\circ} \mathrm{C}$ to obtained serum and kept at $-80{ }^{\circ} \mathrm{C}$ until hormonal and biochemical analysis. After taking blood, testis were dissected out and weigh after washing in saline. Right testicular tissue was stored at $-80{ }^{\circ} \mathrm{C}$ for tissue homogenate tests, while left testes was stored in $10 \%$ phosphate buffered formalin for histological processing. Testicular tissues $(100 \mathrm{mg})$ of each tissue sample was homogenized in 10 volume of $100 \mathrm{mM}$ $\mathrm{KH}_{2} \mathrm{PO}_{4}$ buffer containing $1 \mathrm{mM}$ EDTA, pH 7.4 and centrifuged at $12000 \times \mathrm{g}$ for $30 \mathrm{~min}$ at $4{ }^{\circ} \mathrm{C}$. The supernatant was collected and used for the determination of various biochemical markers.

\section{Hormone analysis}

Testosterone concentration in the serum sample of experimental groups was determined through Astra Biotech kit, Immunotech Company. Concentration of $\mathrm{LH}$ and FSH in the serum of different treatment groups were estimated through GenWay Biotech, Inc. Immunoassay Test Kits.

\section{Protein estimation}

The total protein content of homogenate was determined by total protein kit (AMP Diagnostics, Austria) using bovine serum albumin as a standard. 


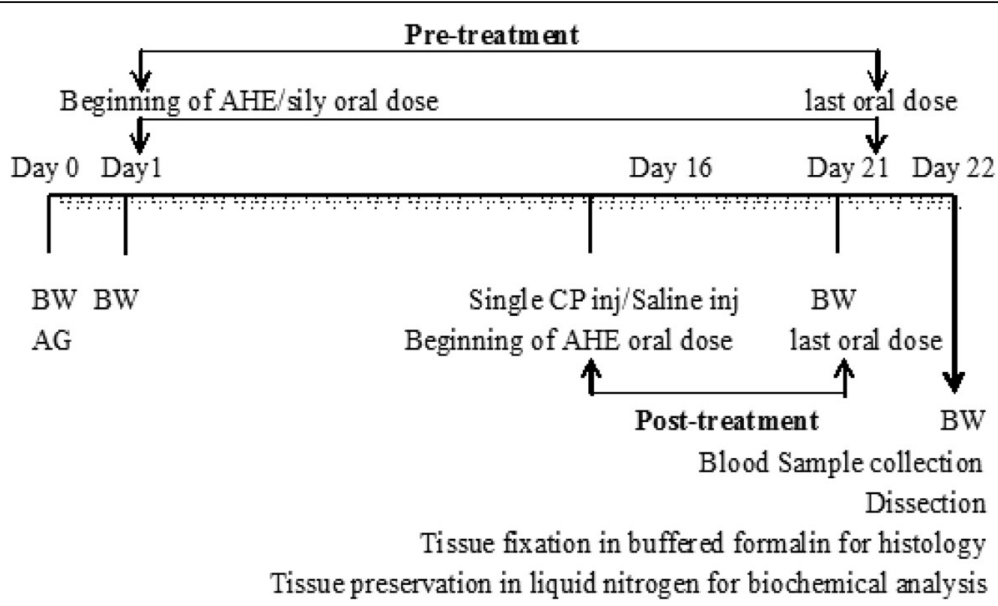

Fig. 1 Time line of experimental protocol. BW: body weight, AG: animal grouping, inj: injection, AHE: A. hydaspica ethyl-acetate extract, CP: cisplatin, Sily:silymarin

\section{Biochemical analysis}

\section{Measurement of tissue antioxidant status}

Catalase (CAT) and Peroxidase (POD) activity was determined by the protocol of Khan et al. with slight modifications [40]. Kakkar et al. method was utilized for the assessment of superoxide dismutase (SOD) activity [41]. The Quinone reductase (QR) activity in tissues of different treatment groups was evaluated as described by Benson and colleagues [42]. Reduced glutathione (GSH) activity was checked as described by protocol of Jollow [43]. Scheme of Habig et al. [44] was followed for the estimation of Glutathione-S-transferase (GST) potency. Glutathione reductase (GR) activity in tissue samples was analyzed as described by Carlberg and Mannervik [45]. Glutathione peroxidase (GPx) activity was assessed as described by Mohandas and coworkers [46]. The activity of $\gamma$-glutamyl transpeptidase $(\gamma$-GT) was checked following Orlowski et al. scheme [47].

\section{Measurement of oxidative stress markers in testis}

Estimation of hydrogen peroxide activity in tissue samples was monitored by the method described earlier [48]. For the execution of nitrite assay, Griess reagent was utilized [49]. Protocol of Iqbal et al. [50] was adopted with slight modifications for the assessment of lipid peroxidation (TBARS/LPO).

\section{DNA damage analysis}

Protective effect of $A$. hydaspica AHE fraction on CP persuaded testicular DNA damage was assessed by comet assay. Single cell gel electrophoresis (Comet assay) was performed by following the protocol of Dhawan et al. [16] to assess the DNA damage in testicular tissues. CASP 1.2.3.b image analysis software was used to evaluate the extent of DNA damage. In each sample, 50-100 cells were analyzed for following prameters by software i. $\quad$ Comet length = Length of the entire comet from left border of head area to end of tail (in pixels)

ii. Tail moment $=$ Tail DNA\% $\mathrm{x}$ Tail Length ([percent of DNA in the tail] $x$ [tail length])

iii. Head DNA = Amount of DNA in the comet head (Sum of intensities of pixels in the head

iv. \% Head DNA = Percent of DNA in the comet head

v. Tail DNA = Amount of DNA in the comet tail (Sum of intensities of pixels in the tail)

vi. \% Tail DNA = Percent of DNA in the comet tail

\section{Histopathological examination by light microscopy}

For histopathological examination, testicular tissues from each group were fixed in a fixative containing absolute alcohol $(85 \mathrm{ml})$, glacial acetic acid $(5 \mathrm{ml})$ and $40 \%$ formaldehyde $(10 \mathrm{ml})$. After dehydration tissue samples were fixed in parafin to prepare blocks for microtomy. Tissues were sectioned 4-5 $\mu \mathrm{m}$ with microtome and stained with Hemotoxilin-Eosin (H\&E) and studied under a light microscope (DIALUX $20 \mathrm{~EB}$ ) at 10X and 40X. Photographs were taken with same the zoom and the camera settings were used and histological parameters were analyzed.

\section{Morphometry and Planimetry}

For morphometric studies, the seminiferous tubule diameter and seminiferous tubule epithelial height of testicular tissue were measured by using Image J software (National Institute of Health, Bethesda, MD, USA) [51]. Shortly, a picture of known distance in micrometer was used for setting scale and conversion of values from pixels to micrometers.

Area of seminiferous tubule and interstitial space was determined by planimetry, using Image J software. The area in $\mu \mathrm{m}^{2}$ was calculated following the method of Islam et al. and Jensen [51, 52]. Briefly, 25 pictures/animal (40X) of known area were selected and the area of seminiferous 
tubules and interstitial space was determined by the free selection tool of the software. The area percentage (\%) was calculated by the formula:

$$
\% \mathrm{AS}=\left[\frac{\mathrm{AS} \times 100}{\mathrm{~T}}\right]
$$

Where AS is the area covered by seminiferous tubule.

$\mathrm{T}$ is the total area of the field.

Percentage of the mean area was analyzed for comparison between the treated and control groups.

\section{Statistical analysis}

Data are expressed mean $\pm \operatorname{SEM}(n=6)$. One way analysis of variance (ANOVA) followed by Tukey's test was used for analyzing the statistical differences between different treatment groups using Graph pad prism 5 software. Level of significance was set at $p<0.05$.

\section{Results}

\section{Acute toxicity evaluation}

Since toxicity of the test sample was a focal concern, hence acute toxicity evaluation was done before proceeding to in vivo experiment. AHE was found to be safe at all tested doses (up to $4000 \mathrm{mg} / \mathrm{kg}$ b.w) and it did not induce any noxious symptom in rats like sedation, convulsions, diarrhea and irritation. During the 3 days of the assessment, no mortality was observed. Therefore, one tenth of the maximum dose, $400 \mathrm{mg} / \mathrm{kg}$ b.w. was used for in vivo evaluation of AHE.

\section{AHE treatment is not associated with toxicity}

In all treatment groups no clinical signs of toxicity (such as, unusual salivation, flick-king movements, shiver, head and forelimb clonuses, spasms, incoordination, diarrhea and increased diuresis) were observed. No death was witnessed in any treatment group during the experimental period. The testicular tissues from either control or AHE treated rats revealed no obvious variations in histo-architecture (Fig. 2a and b). The animals treated with AHE showed similar body weight gain compared to the control group (Fig. 2c). Similarly, no significant change in testicular weight was recorded in AHE and control groups (Fig. 2d), suggesting that there was no toxicity associated with AHE dosage. The results strongly suggest the protective effect of AHE treatment with no adverse effects associated with treatment.

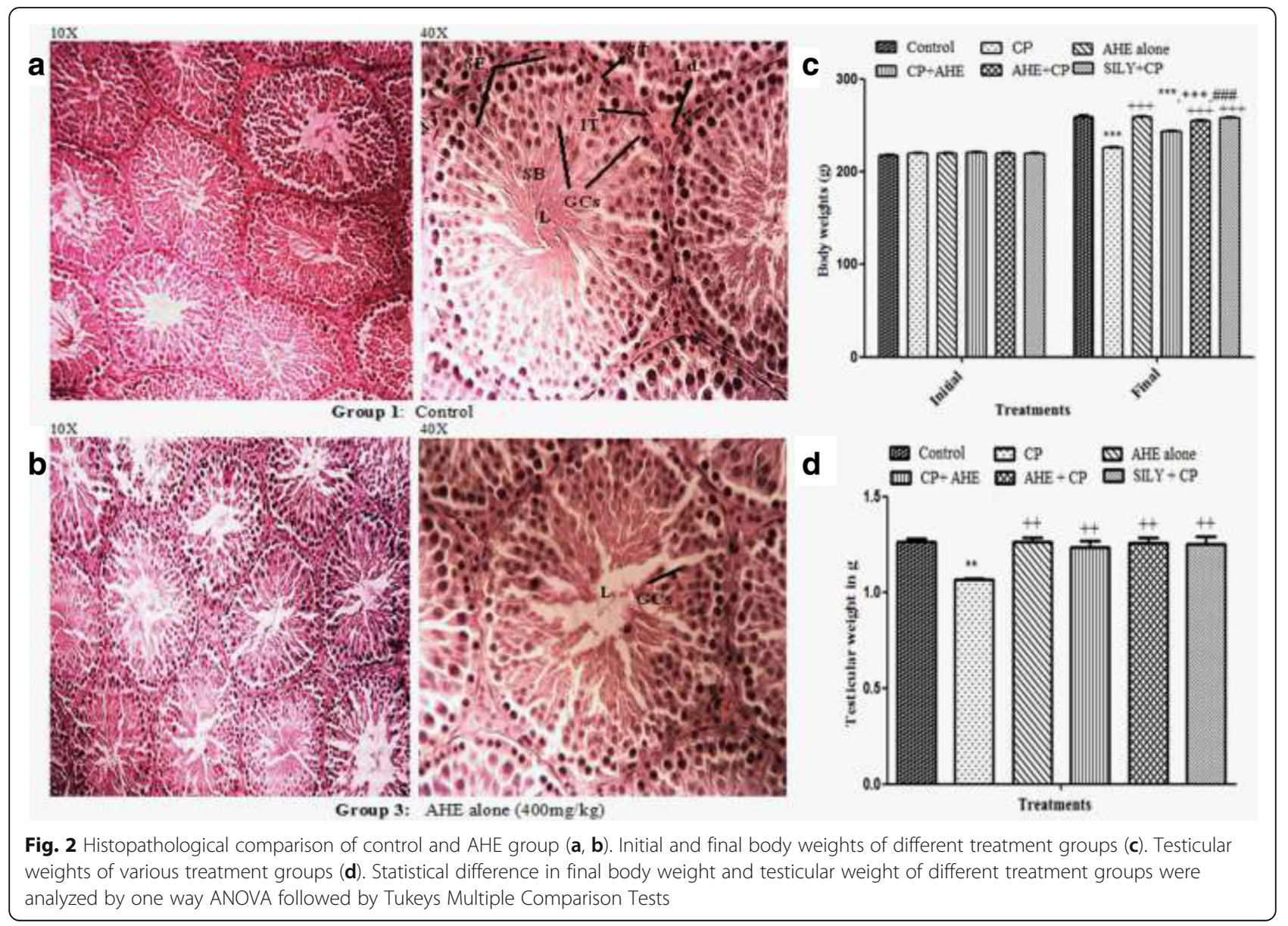


Effect of AHE treatment on male reproductive hormones of rat

Reproductive hormones such as testosterone (T), luteinizing hormone (LH) and follicle stimulating hormone (FSH) are considered as imperative serological biomarkers to estimate testicular toxicity. The serological concentration of T, LH and FSH are highly susceptible to oxidative stress induced by $\mathrm{CP}$ as shown in Table 2, indicating that $\mathrm{CP}$ administration altered the secretion of pituitary and gonadal hormones. CP inoculation significantly $(p<0.0001)$ decreased the concentration of serum T, LH and FSH which was ameliorated significantly $(p<0.0001)$ by oral administration of AHE compared to CP group, however the hormonal concentration did not restore to normalized control values. However, AHE alone showed the same serum hormone concentration like that of control group. AHE $+\mathrm{CP}$ treatment was more effective $(p<0.0001)$ as compared to $\mathrm{CP}+\mathrm{AHE}$ in preventing $\mathrm{CP}$ intoxication signifying the protective role of AHE. $\mathrm{AHE}+\mathrm{CP}$ exhibited analogous effect on serum reproductive hormone concentration as a $\mathrm{CP}+$ silymarin treated group.

\section{Effect of AHE on enzymatic antioxidants and oxidative stress markers in testis}

Development of testicular impairment followed by CP exposure is mainly ascribed to free radical intervened oxidative distress and attenuation of antioxidant defense system. The effect of AHE treatments against CP intoxication of the antioxidant enzyme system are depicted in Tables 3 and 4. SOD (phase I antioxidant enzyme) causes dismutation of superoxide radicals to hydrogen peroxide $\left(\mathrm{H}_{2} \mathrm{O}_{2}\right)$, while CAT and POD transform $\mathrm{H}_{2} \mathrm{O}_{2}$ to water and defend the cell from oxidative injury. Our results indicated the ability of $\mathrm{CP}$ to cause significant impairment on testicular tissue by decreasing the tissue protein content as well as CAT, POD, SOD and QR levels in addition to increasing the lipid peroxidation (TBARS) and $\mathrm{H}_{2} \mathrm{O}_{2}$ contents as opposed to control group (Tables 2 and 4 ).
$\mathrm{CP}+\mathrm{AHE}$ and $\mathrm{AHE}+\mathrm{CP}$ treatments significantly augment the suppressed protein content and antioxidant enzyme activity while decreasing the oxidative stress markers in contrast to $\mathrm{CP}$ alone treated group (Tables 3 , 4 and 5$)$. AHE + CP more efficiently $(p<0.001)$ prevented the $\mathrm{CP}$ deleterious effects as compared to $\mathrm{CP}+\mathrm{AHE}$ treatment group.

The effects of AHE treatment on phase II antioxidant enzymes like GSH, GR, GST, $\gamma$-GT and GPx, of testicular tissues are displayed in Table 3. CP administration extensively $(p<0.0001)$ decreased the glutathione status of GSH and the activity level of GR, GST, $\gamma-$ GT and GPx while amplifing oxidative stress markers like $\mathrm{NO}, \mathrm{H}_{2} \mathrm{O}_{2}$ and TBARS content (Table 4) in comparison to that of control group. In AHE + CP group GSH and GPx levels completely recovered to that in the control group. $\mathrm{AHE}+\mathrm{CP}$ resulted in more significant $(p<0.001)$ improvement as compared to $\mathrm{CP}+\mathrm{AHE}$ group, indicative of the protective effect of AHE against $\mathrm{CP}$ induced deteriorations. The effects of $\mathrm{AHE}+\mathrm{CP}$ on testicular antioxidant enzymes were comparable to that of $\mathrm{CP}+$ silymarin treated group. Moreover, AHE alone presented nonsignificant changes in the activity level of testis antioxidant enzymes, protein content, oxidative stress markers and lipid peroxidation when compared to control group, indicating the nontoxic effect of the plant fraction.

\section{Effect of AHE treatment on testicular histology and morphometry}

Figure 3 shows the histological examination of testicular tissues from different treated groups. Slides were studied at 10X and 40X magnifications. At 40X concentration, morphology and the stages of germ cells were observed while at 10X, spaces between the seminiferous tubules were examined between different treatment groups. Histopathological findings revealed the normal organization of germinal and Sertoli cells and active spermatogenesis in the seminiferous tubules without any histopathological injuries in control and AHE alone group (Fig. 1). CP inoculated animals presented inexorable testicular atrophy with austere cellular disorganizations, degenerations in

Table 2 Effect of cisplatin (CP) and different treatments of AHE on male reproductive hormones

\begin{tabular}{llll}
\hline Group & $\mathrm{T}(\mathrm{ng} / \mathrm{ml})$ & $\mathrm{LH}(\mathrm{mlU} / \mathrm{ml})$ & $\mathrm{FSH}(\mathrm{mlU} / \mathrm{ml})$ \\
\hline Control & $4.55 \pm 0.09$ & $2.30 \pm 0.04$ & $1.46 \pm 0.012$ \\
CP & $2.32 \pm 0.06^{* * *}$ & $1.32 \pm 0.02^{* * *}$ & $0.79 \pm 0.035^{* * *}$ \\
AHE alone & $4.59 \pm 0.06^{+++}$ & $2.31 \pm 0.04^{+++}$ & $1.46 \pm 0.013^{+++}$ \\
CP + AHE & $2.85 \pm 0.09^{* *,+++, \# \#+}$ & $1.46 \pm 0.02^{* * *,+, \# \#+}$ & $1.00 \pm 0.053^{* * *,+++, \# \#+}$ \\
AHE + CP & $4.20 \pm 0.07^{*,+++}$ & $2.09 \pm 0.06^{*,+++}$ & $1.32 \pm 0.022^{*,+++}$ \\
CP + Sily & $4.16 \pm 0.04^{*,+++}$ & $2.08 \pm 0.06^{* *+++}$ & $1.31 \pm 0.013^{* *++++}$ \\
\hline
\end{tabular}

$n=6 /$ group; values are expressed as mean $\pm \mathrm{SEM} ;{ }^{*}{ }^{* *},{ }^{* * *}$ indicate significance from the control group as mean $\pm \mathrm{SEM}$ at $p<0.05, p<0.001$ and $p<0.0001$ probability level, respectively; ${ }^{++},+++$indicate significance from the CP group at $p<0.001$ and $p<0.0001$ probability level, respectively; \#\#\# indicates comparison of $\mathrm{AHE}+\mathrm{CP}$ pre-treated group vs. $\mathrm{CP}+\mathrm{AHE}$ post-treated group at $p<0.0001$ probability level. Non-signigicant difference was recorded between control and AHE alone group (One way ANOVA followed by Tukey's multiple comparison) 
Table 3 Effect of cisplatin (CP) and different treatments of AHE on testicular tissue antioxidant enzymes

\begin{tabular}{|c|c|c|c|c|}
\hline Group & POD (U/min) & SOD (U/mg protein) & CAT (U/min) & $\mathrm{QR}$ (nM/min/mg protein) \\
\hline Control & $14.95 \pm 0.34$ & $1.413 \pm 0.02$ & $17.35 \pm 0.16$ & $141.7 \pm 0.87$ \\
\hline $\mathrm{CP}$ & $8.92 \pm 0.35^{* * *}$ & $0.787 \pm 0.03^{* * *}$ & $10.48 \pm 0.153^{* * *}$ & $94.26 \pm 0.78^{* * *}$ \\
\hline AHE alone & $15.13 \pm 0.29^{+++}$ & $1.402 \pm 0.014^{+++}$ & $17.95 \pm 0.167^{+++}$ & $142.3 \pm 0.754^{+++}$ \\
\hline $\mathrm{CP}+\mathrm{AHE}$ & 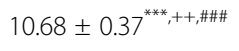 & 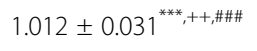 & 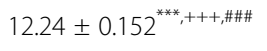 & $101.9 \pm 0.909^{* * *,+++, \# \# \#}$ \\
\hline $\mathrm{AHE}+\mathrm{CP}$ & $13.42 \pm 0.22^{*,+++}$ & $1.377 \pm 0.061^{+++}$ & $16.91 \pm 0.194^{+++}$ & $137.6 \pm 0.974^{*,+++}$ \\
\hline $\mathrm{CP}+$ Sily & $13.504 \pm 0.23^{*++++}$ & $1.321 \pm 0.026^{+++}$ & $16.97 \pm 0.20^{+++}$ & $137.4 \pm 0.755^{* .+++}$ \\
\hline
\end{tabular}

$n=6 /$ group; values are expressed as mean $\pm \mathrm{SEM} ;{ }^{*},{ }^{* *},{ }^{* * *}$ indicate significance from the control group at $p<0.05, p<0.001$ and $p<0.0001$ probability level, respectively; ${ }^{++},+++$indicate significance from the $\mathrm{CP}$ group at $p<0.001$ and $p<0.0001$ probability level, respectively; \#\#\# indicates comparison of $\mathrm{AHE}+\mathrm{CP}$ pre-treated group vs. CP + AHE post treated group at $p<0.0001$ probability level. Non-significant difference $(p>0.05)$ was recorded between control and AHE alone treated group in all parameters. (One way ANOVA followed by Tukeys multiple comparison tests)

seminiferous tubules and interstitium, and decreased thickness of germinal epithelium. CP inoculation also impelled the diminution of Leydig cells amongst the tubules and attenuated several stages in spermatogenesis. Disintegrated Sertoli cells were also noticed in the lumen. These alterations were markedly reduced with oral administration of AHE. Post treatment showed a protective effect in comparison to the $\mathrm{CP}$ group, yet maximum protection was seen in pretreatment group. Rats pre-treated with $\mathrm{AHE}$ and $\mathrm{CP}+$ silymarin displayed normal testicular morphology with trivial irregularities in germ cells arrangements and minor disintegration of seminiferous epithelium, moreover cell in various stages were observable showing active spermatogenesis. Current data showed that pre-treatment AHE extract offers more protection against the histopathological lesions impelled by CP in comparison to its administration after CP dose.

The seminiferous tubule diameter and epithelial height were reduced $(p<0.001)$ in the CP alone treated group when compared to the control group. However, in AHE $+\mathrm{CP}$ treated animals, tubular diameter and epithelial height showed significant increase $(p<0.0001)$ as compared to the CP alone treated group (Table 6). CP + AHE group showed significant $(p<0.001)$ improvement in seminiferous tubule diameter, but no effect on epithelial height was observed in comparison to CP group. Tubular lumen was significantly $(p<0.0001)$ increased in $\mathrm{CP}$ group compared to control, while AHE in both treatments significantly reduced the wide tubule lumen. Similarly, the area of the seminiferous tubule/unit area (\%) was significantly decreased in the CP treated group as compared to the control group. A significant increase in the seminiferous tubule area was found in the $\mathrm{CP}+$ $\mathrm{AHE}$ and $\mathrm{AHE}+\mathrm{CP}$ treated groups $(p<0.0001)$ when compared to the $\mathrm{CP}$ alone treated group (Table 5).The interstitial space (\%) in unit area was significantly increased $(p<0.0001)$ in the CP treated group as compared to the control group. A significant reduction in interstitial space (\%) was observed in the both $\mathrm{CP}+\mathrm{AHE}$ and $\mathrm{AHE}+\mathrm{CP}$ groups when compared with the $\mathrm{CP}$ treated group $(p<0.0001)$ (Table 6). Histopathological findings reinforced that $A$. hydaspica possesses the protective potential against $\mathrm{CP}$-induced testicular toxicity and these results are in agreement of other investigated parameters.

\section{Effect of AHE treatment on cisplatin induced DNA damage}

Figure 4 depicts microphotograph of different treatment groups and protective potential of AHE on genotoxicity. Maximum DNA damage was obsereved in CP treated group (4b). Figure 5 depicts the quantitative analysis of different comet scoring parameters studied. Greater proportion of cells with intact DNA (5a), less concentration of tail DNA (5b), reduced tail movement (5c) and an insignificant number of comets with very tiny tail length (5d)

Table 4 Effect of cisplatin (CP) and different treatments of AHE on testicular tissue antioxidant enzymes and GSH profile

\begin{tabular}{|c|c|c|c|c|c|}
\hline Group & GSH ( $\mu \mathrm{M} / \mathrm{g}$ tissue) & $\mathrm{GR}$ (nM/min/mg protein) & GST (nM/min/mg protein) & Y-GT (nM/min/mg Protein) & $\mathrm{GPx}(\mathrm{nM} / \mathrm{min} / \mathrm{mg}$ Protein) \\
\hline Control & $17.84 \pm 0.77$ & $158.4 \pm 1.09$ & $133.1 \pm 0.95$ & $326.5 \pm 0.44$ & $131.5 \pm 1.72$ \\
\hline $\mathrm{CP}$ & $8.48 \pm 0.415^{* * *}$ & $110.7 \pm 1.29^{* * *}$ & $96.14 \pm 0.84^{* * *}$ & $106.9 \pm 0.59^{* * *}$ & $69.42 \pm 1.62^{* * *}$ \\
\hline AHE alone & $17.87 \pm 0.54^{+++}$ & $159.6 \pm 1.19^{+++}$ & $133.4 \pm 1.25^{+++}$ & $329.4 \pm 0.90^{+++}$ & $132.2 \pm 0.98^{+++}$ \\
\hline $\mathrm{CP}+\mathrm{AHE}$ & 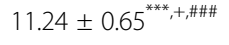 & 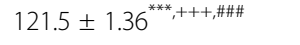 & 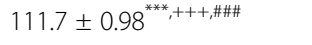 & 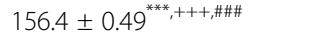 & $83.91 \pm 1.06^{* * *,+++, \# \# \#}$ \\
\hline $\mathrm{AHE}+\mathrm{CP}$ & $16.06 \pm 0.30^{+++}$ & $150.1 \pm 1.14^{* *++++}$ & $128.4 \pm 0.92^{*,+++}$ & $309.1 \pm 0.89^{* * *,+++}$ & $126.2 \pm 0.91^{+++}$ \\
\hline $\mathrm{CP}+$ Sily & $16.15 \pm 0.50^{+++}$ & $149.2 \pm 1.72^{* *,+++}$ & $128.2 \pm 0.83^{*,+++}$ & $312.5 \pm 1.03^{* * *,+++}$ & $126.3 \pm 1.25^{+++}$ \\
\hline
\end{tabular}

$n=6 /$ group; values are expressed as mean $\pm \mathrm{SEM}^{*}{ }^{*, * *},{ }^{* * * *}$ indicate significance from the control group at $p<0.05, p<0.001$ and $p<0.0001$ probability level, respectively; ${ }^{+++}$indicate significance from the $\mathrm{CP}$ group at $p<0.0001$ probability level; \#\#\# indicates comparison of $\mathrm{AHE}+\mathrm{CP}$ pre-treated group vs. $\mathrm{CP}+\mathrm{AHE}$ post-treated group at $p<0.0001$ probability level. Non-significant difference $(p>0.05)$ was recorded between control and AHE alone treated group in all parameters (One way ANOVA followed by Tukey's multiple comparison tests) 
Table 5 Effect of cisplatin (CP) and different treatments of AHE on testicular tissue protein, and oxidative stress markers

\begin{tabular}{|c|c|c|c|c|}
\hline Group & Protein ( $\mu \mathrm{g} / \mathrm{mg}$ Tissue) & $\mathrm{H}_{2} \mathrm{O}_{2}$ (nM/min/mg Tissue) & Nitrite content $(\mathrm{NO} \mu \mathrm{M} / \mathrm{ml})$ & MDA (nM/min/mg protein) \\
\hline Control & $1.558 \pm 0.01$ & $2.408 \pm 0.09$ & $41.97 \pm 0.52$ & $3.031 \pm 0.12$ \\
\hline $\mathrm{CP}$ & $0.944 \pm 0.04^{* * *}$ & $5.825 \pm 0.06^{* * *}$ & $80.05 \pm 0.62^{* * *}$ & $9.713 \pm 0.18^{* * *}$ \\
\hline AHE alone & $1.561 \pm 0.05^{+++}$ & $2.349 \pm 0.02^{+++}$ & $40.92 \pm 0.37^{+++}$ & $2.95 \pm 0.15^{+++}$ \\
\hline $\mathrm{CP}+\mathrm{AHE}$ & $1.352 \pm 0.05^{* * *},+++, \# \# \#$ & $4.568 \pm 0.02^{* * *},+++, \# \# \#$ & 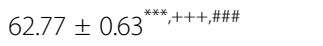 & 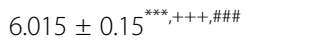 \\
\hline $\mathrm{AHE}+\mathrm{CP}$ & $1.516 \pm 0.03^{+++}$ & $3.216 \pm 0.01^{* * *,+++}$ & $44.80 \pm 0.48^{*,+++}$ & 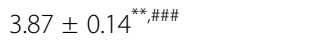 \\
\hline $\mathrm{CP}+$ Sily & $1.540 \pm 0.02^{+++}$ & $3.145 \pm 0.01^{* * *,+++}$ & $44.23 \pm 0.76^{+++}$ & 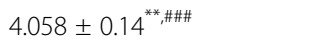 \\
\hline
\end{tabular}

$n=6 /$ group; values are expressed as mean $\pm \mathrm{SEM} ;{ }^{*},{ }^{* *},{ }^{* * *}$ indicate significance from the control group at $p<0.05, p<0.001$ and $p<0.0001$ probability level, respectively; ${ }^{++},+++$indicate significance from the CP group at $p<0.001$ and $p<0.0001$ probability level, respectively; \#\#\# indicates comparison of AHE + CP pre-treated group vs. CP + AHE post-treated group at $p<0.0001$ probability level. Non-significant difference $(p>0.05)$ was recorded between control and AHE alone treated group in all parameters (One way ANOVA followed by Tukey's multiple comparison tests)

were observed in control group. CP inoculation induced DNA demage and resulted in significant $(P<0.0001)$ increase in tail DNA concentration (Fig. 5b), tail movement (Fig. 5c) and comet length (Fig. 5d) while marked $(P<0.0001)$ decrease in concentration of DNA in comet head was recorded (Fig. 5a). Treatment with AHE ameliorated the CP-induced DNA damages and the comet values were restored towards the control level (Fig. 5). AHE + CP reduced the DNA damages more convincingly $(p<0.001)$ as compared to $\mathrm{CP}+\mathrm{AHE}$ treated group, specifying the preventing potency of AHE. Concentration of DNA in head was sharply enhanced in head of comet along with significant $(P<0.0001)$ decrease in tail moment with the AHE pretreatment was noticed.Treatment of $\mathrm{AHE}+\mathrm{CP}$ showed equal potency as $\mathrm{CP}+$ silymarin in protecting the testicular DNA damages and restored the comet values

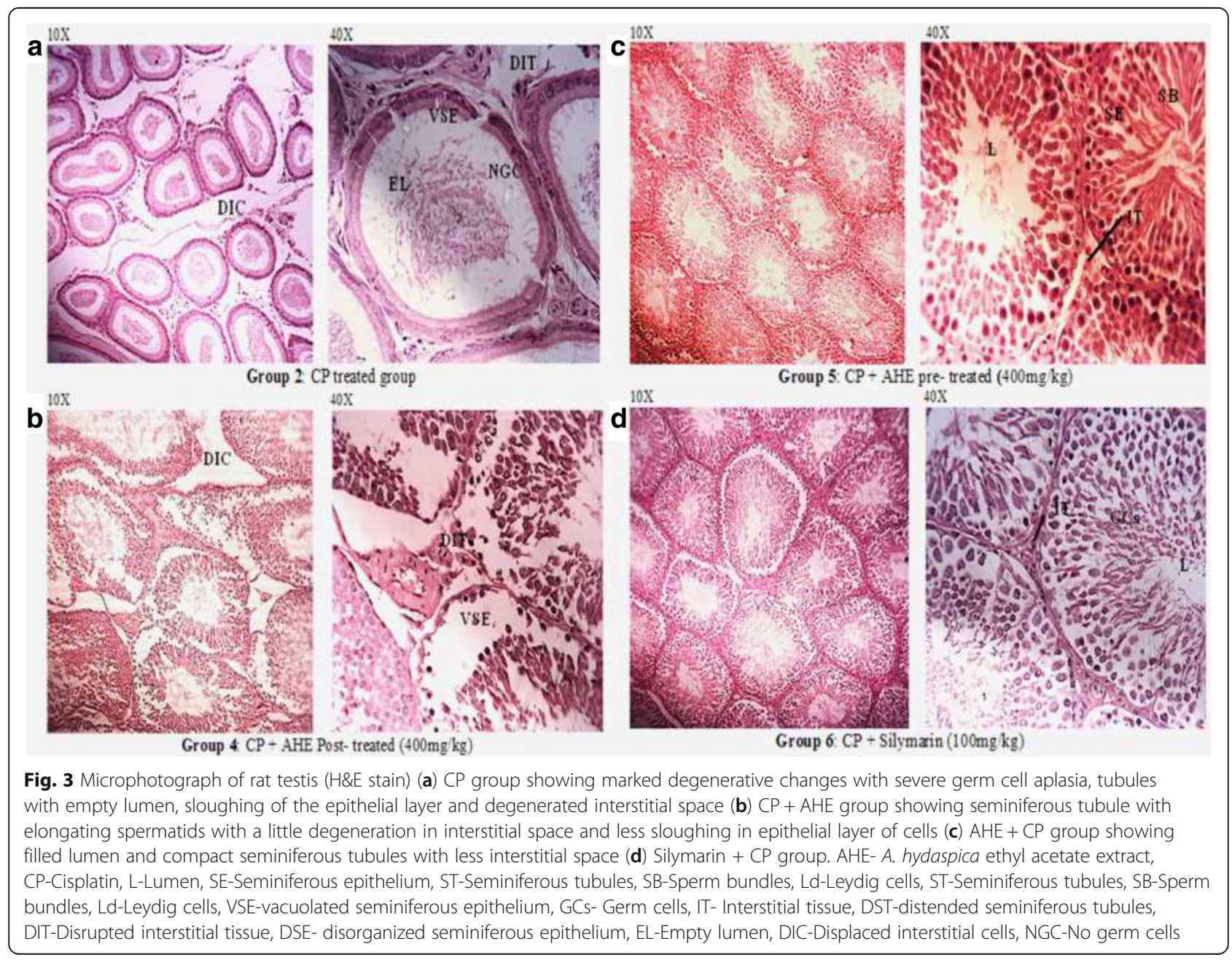


Table 6 Effect of AHE treatment on testicular morphometric parameters in different experimental groups

\begin{tabular}{llllll}
\hline Groups $(n=6)$ & $\begin{array}{l}\text { Seminiferous tubule } \\
\text { diameter }(\mu \mathrm{m})\end{array}$ & $\begin{array}{l}\text { Seminiferous tubule } \\
\text { epithelial height }(\mu \mathrm{m})\end{array}$ & Tubular lumen $(\mu \mathrm{m})$ & $\begin{array}{l}\text { Seminiferous } \\
\text { tubule area }(\%)\end{array}$ & $\begin{array}{l}\text { Interstitial } \\
\text { space }(\%)\end{array}$ \\
\hline Control & $177.4 \pm 2.04$ & $70.90 \pm 1.25$ & $9.89 \pm 0.63$ & $86.29 \pm 1.05$ & $13.7 \pm 1.05$ \\
CP & $163.9 \pm 1.60^{* * *}$ & $21.15 \pm 0.86^{* * *}$ & $66.48 \pm 0.61^{* * *}$ & $45.44 \pm 0.64^{* * *}$ & $54.56 \pm 0.64^{* * *}$ \\
AHE alone & $173.7 \pm 1.54^{+++}$ & $71.52 \pm 0.99^{+++}$ & $9.99 \pm 0.65^{+++}$ & $86.69 \pm 0.60^{+++}$ & $13.31 \pm 0.54^{+++}$ \\
CP + AHE & $168.8 \pm 1.24^{* *++, \# \#}$ & $24.18 \pm 1.09^{* * *, \# \#}$ & $63.27 \pm 0.72^{* * *+,+\# \# \#}$ & $69.33 \pm 0.41^{* * *,+++, \# \#}$ & $30.67 \pm 0.42^{* * *++++, \# \#}$ \\
AHE + CP & $178.3 \pm 1.62^{+++}$ & $66.03 \pm 0.68^{*,+++}$ & $11.18 \pm 0.60^{+++}$ & $82.22 \pm 0.60^{* *+++}$ & $17.78 \pm 0.60^{* *++++}$ \\
CP + Sily & $173.8 \pm 1.25^{+++}$ & $66.33 \pm 0.79^{*,+++}$ & $11.43 \pm 0.47^{+++}$ & $82.44 \pm 0.35699^{* *,+++}$ & $17.56 \pm 0.35^{* *+++}$ \\
\hline
\end{tabular}

$n=6 /$ group; data presented as mean \pm SEM; *** indicate significance from control group at $p<0.0001$ probability level,,++++ indicate significance from CP group at $p<0.05$ and $p<0.0001$ probability level, \#\#,\#\#\# indicate significance from AHE + CP group at $p<0.001$ and $p<0.0001$ probability level respectively
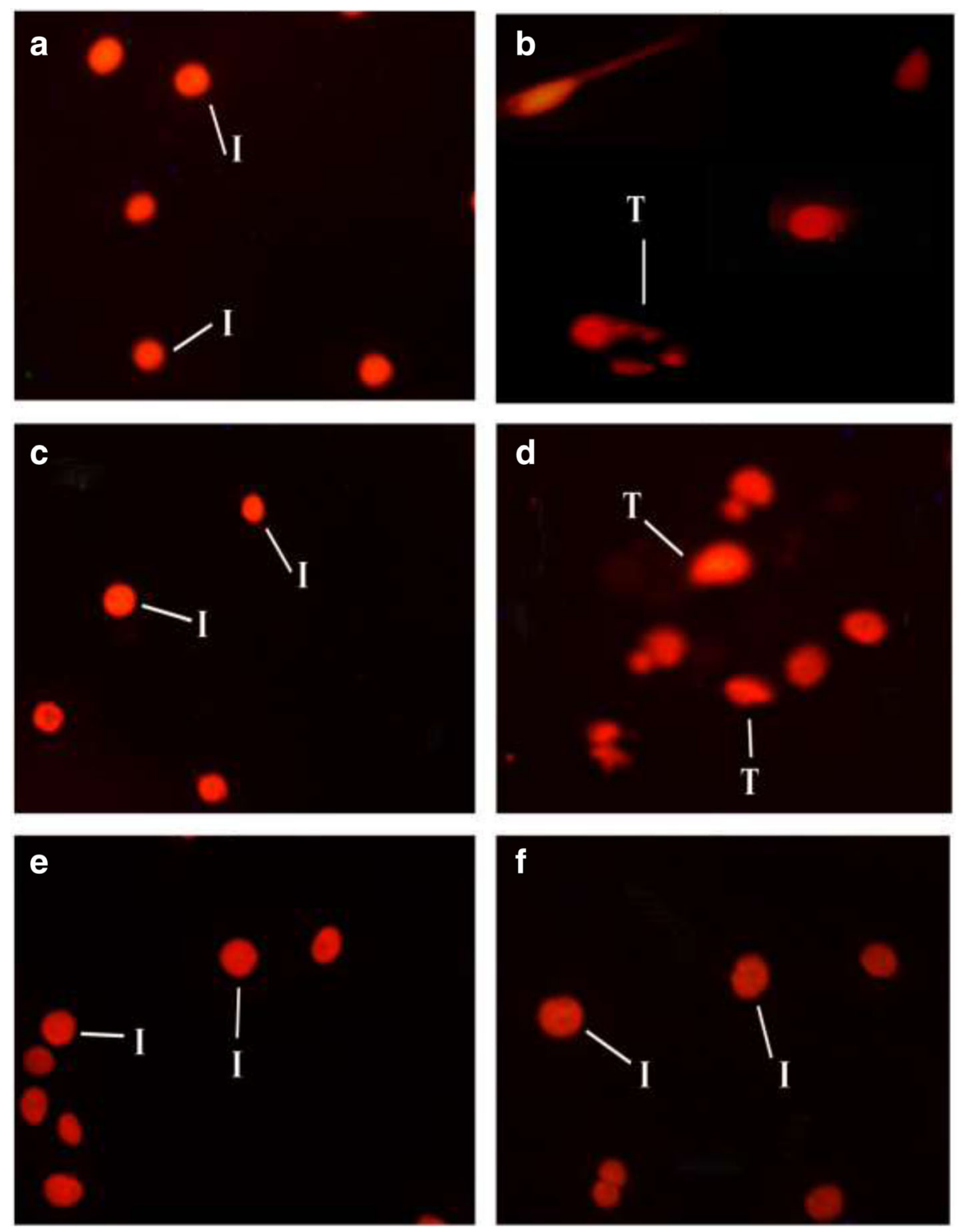

Fig. 4 Fluorescence photomicrograph of testicular cells revealing protective effect of AHE against CP induced genotoxicity. a Control group, b CP (7.5 ml/kg b.w, i.p), c AHE alone, $\mathbf{d}$ CP + AHE, e AHE + CP,f Silymarin + CP. I: Intact Comet head; T, Comet tail 

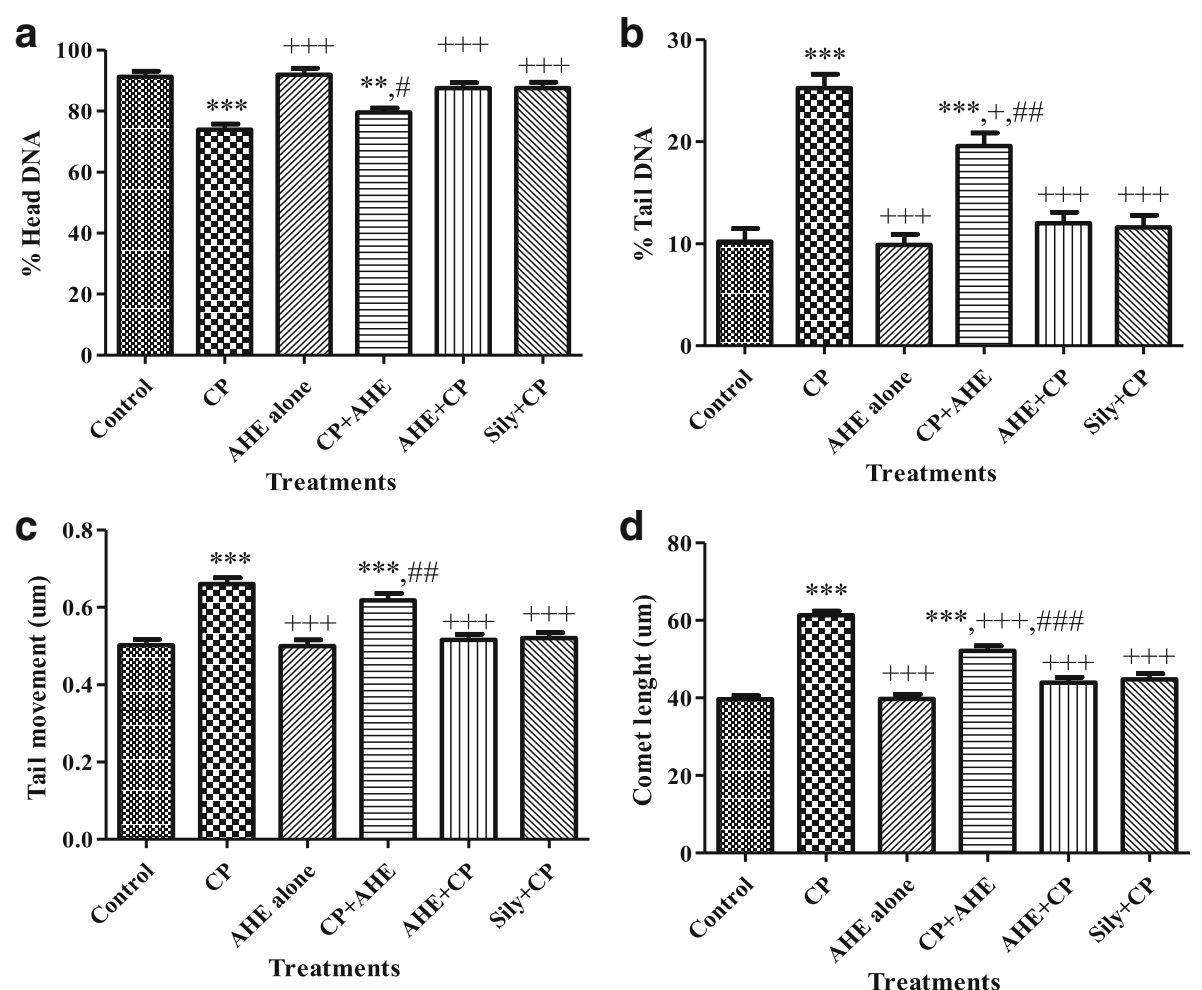

Fig. 5 Comet scoring parameters indicating the protective effect of AHE against CP induced DNA damages. a Percent head DNA, b Percent tail DNA, c Tail movement $(\mu \mathrm{m})$, d Comet lengh $(\mu \mathrm{m}) . n=6 /$ group; data presented as mean $\pm \mathrm{SEM}^{* *},{ }^{* * *}$ indicate significance from control group at $p<0.001$ and $p<0.0001$ probability level,,++++ indicate significance from CP group at $p<0.05$ and $p<0.0001$ probability level, \#\#, \#\#\# indicate significance from AHE + CP group at $p<0.001$ and $p<0.0001$ probability level respectively

towards the control group. AHE administration to rats resulted in non-significant differences in comet parameters compared to control group.

\section{Discussion}

Male germ cells are known to be one of the tissues prone to $\mathrm{CP}$ toxicity. CP treatment, causes testicular toxicity by inducing oxidative stress, spermatotoxicity and DNA damage; which results infertility-causing complications and hence, the protection of testicular tissue remains a critical issue whenever $\mathrm{CP}$ is employed in cancer chemotherapy $[4,10,53,54]$. The therapeutic potential of medicinal plants is accredited to their secondary metabolites. The scavenging of free radicals by the plant derived product may offer a natural alternative method to tackle oxidative stress persuaded tissue damages. Polyphenolic compounds play an important role in the prevention of $\mathrm{CP}$ induced oxidative trauma and testicular injuries [1].

In the present study, we measured several biochemicals, hormonal and histological parameters related to testicular toxicity and oxidative stress in the testis tissue to evaluate the protective effect of AHE against CPinduced reproductive toxicity in male rats.
Our findings on $\mathrm{CP}$ induced testicular impairment endorsed the previous findings that $\mathrm{CP}$ treatment causes biochemical and testicular tissue alterations such as in germinal epithelium and long term failure of spermatogenesis due to its alkylation property $[9,53,55]$. The earlier work of Turk et al. also demonstrated that CP decreased the testicular weight, epididymis and seminal vesicle in treated rats [56]. However, different mechanisms have been anticipated on the damaging aspect of the drug. A strategy to decrease the prevalence of severe lateral-influences of anticancer drugs with conservation of its chemotherapeutic usefulness is indispensable.

Serum gonadotropin releasing hormone $(\mathrm{GnRH})$ including LH, FSH and T levels aid in making conclusions regarding reproductive pathologies. The fall in serum $\mathrm{T}$ concentration describes either direct effect of the chemical at Leydig cell level or an indirect action via alteration in hormonal regulation of hypothalamic-pituitary axis (HPA) due to oxidative stress in drug treated animals [57]. It was also reported that abnormal concentration of intratesticular testosterone inhibit spermatogenesis [58]. The production of testosterone in Leydig cells is stimulated by LH, which activates FSH to bind with Sertoli cells to stimulate spermatogenesis [33]. The outcome of current investigation with 
reference to the testicular function marker enzymes in serum, revealed that CP exhibited a noteworthy suppression of T, LH and FSH concentrations. The suppression of $\mathrm{T}$ by $\mathrm{CP}$ has been reported previously [59], however, the effect of CP on LH and FSH in our investigation is in contradiction as they reported that $\mathrm{CP}(7.5 \mathrm{mg} / \mathrm{kg}$, iv $)$ administration did not alter serum LH or FSH while it decrease serum and testicular testosterone [60]. Garcia et al. also reported that the inhibitory potential of $\mathrm{CP}$ on testosterone synthesis was due to ROS [61, 62]. Administration of AHE results in potential intensification of lowered levels of T, LH and FSH and might result in regulation of HPA. The decrease in serum testosterone might be consequent of direct toxic effect of $\mathrm{CP}$ on the Leydig cells, as previous study revealed that antineoplastic agents can disrupt Leydig cells directly [63]. Steroidogenesis in the male rats is triggered by $\mathrm{GnRH}$, which elicit the production and release of $\mathrm{LH}$, which then binds to $\mathrm{LH}$ receptors on the membrane of Leydig cells to upregulate testosterone production [64]. The reduction in serum LH level observed in current study possibly is the outcome of impairment in the negative feedback mechanism of hypothalamic-pituitary axis [65]. $\mathrm{AHE}+\mathrm{CP}$, more significantly maintained serum hormone levels compared to $\mathrm{CP}+\mathrm{AHE}$, indicating the preventive potential of AHE. Furthermore, reduction in the weight of the testes in $\mathrm{CP}$ treated rats revealed the reduced availability of androgens [66].
Oxidative stress, a situation of disproportion between the free radicals and antioxidant defense system, is an imperative cause in the pathogenesis of various ailments [67]. The level of antioxidant enzymes, including SOD, POD, CAT, QR as well as GSH, GPx, GR, GST and gamma GT were assessed to determine the potential protective influence of AHE against $\mathrm{CP}$ induced oxidative stress mediated gonadotoxicity in mature male rats. Furthermore, TBARS as a marker of lipid peroxidation and $\mathrm{H}_{2} \mathrm{O}_{2}$ and $\mathrm{NO}$ levels as a marker of oxidative and nitrosative stress were estimated in testicular tissue. Previous studies authenticated the prominence of oxidative stress in the pathogenesis of $\mathrm{CP}$ mediated gonadotoxicity $[54,66]$. The unnecessary concentration of ROS in the cisplatin treated rats makes spermatozoa extremely liable to impairment due to the high content of polyunsaturated fatty acids in their plasma membrane [68]. Moreover, Sharma and Agarwal reported that enhanced lipid peroxidation in $\mathrm{CP}$ treated rats, destroys the structure of spermatozoa accompanied by the loss of its motility and impairment of spermatogenesis [69]. The AHE + CP as well as $\mathrm{CP}+\mathrm{AHE}$ treatment strategies produced a potential increase in depleted antioxidant enzyme levels in the welfare of oxidative trauma in vivo. AHE treatment significantly ameliorated the increased levels of oxidative stress markers, i.e. TBARS, $\mathrm{H}_{2} \mathrm{O}_{2}$ and $\mathrm{NO}$, and pre-treatment restored the levels near normal. The antioxidant enzyme

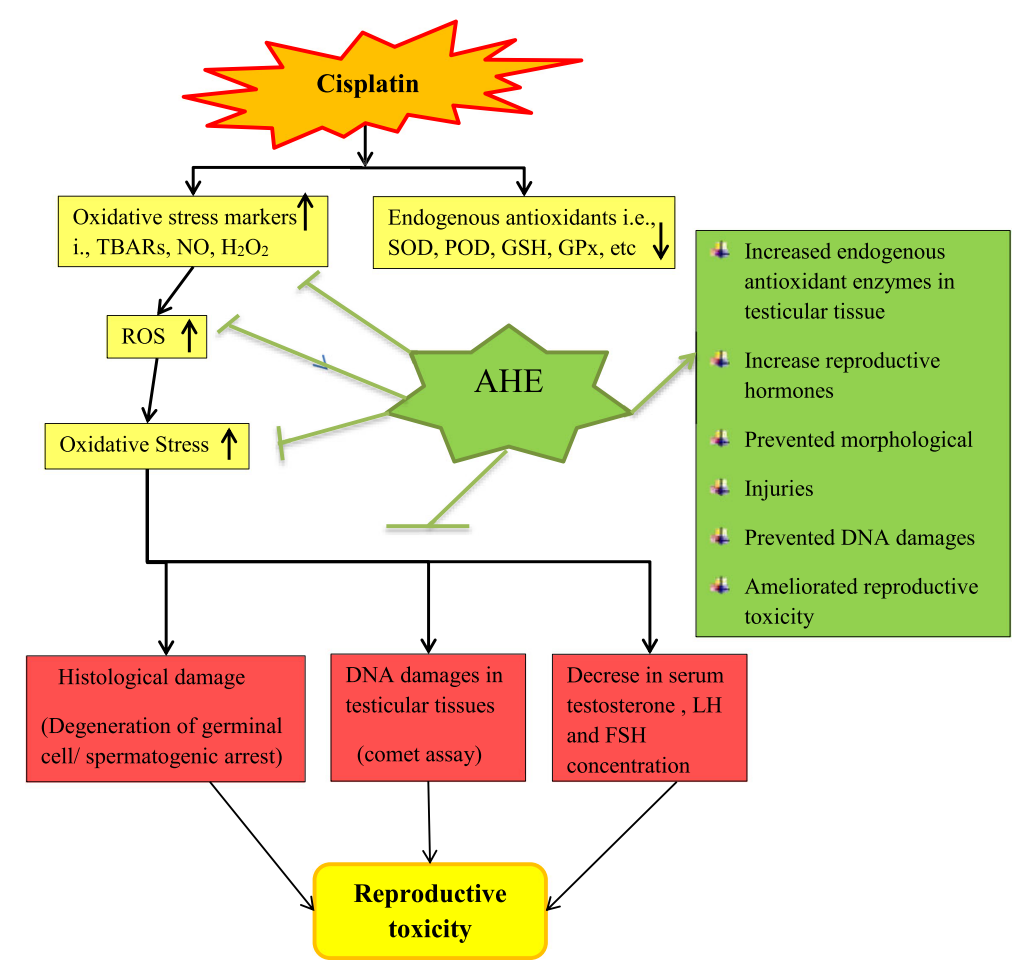

Fig. 6 Hypothetical pathway describing the possible underlying mechanism of CP induced reproductive toxicity and protective effect of AHE 
levels showed noticeable increase while oxidative stress marker levels were significantly diminished in AHE $+\mathrm{CP}$ group in comparison with $\mathrm{CP}+\mathrm{AHE}$. The mechanism behind AHE protective antioxidant effect might be due to its flavonoids enrichment; as flavonoids from plants and fruits were potent $\mathrm{OH} \bullet, \mathrm{O}_{2} \bullet-$ scavengers, chelate metal ions and exert a synergistic effect with other antioxidant metabolites [58]. We strongly beleive that polyphenolic compounds of AHE might be responsible for the preventing $\mathrm{CP}$ induced testicular impairments.

The testicular protein level showed a significant decrease in CP treated groups compared to control. During abnormal spermatogenesis, the testicular proteins become demolished [70]. The highly significant reduction in protein content in $\mathrm{CP}$ treated group may be due to defective spermatogenesis.

Testicular histomorphology of $\mathrm{CP}$ treated groups revealed severe spermatogenesis impairment, increase in germ cell death and testicular atrophy, causing degenerative vicissitudes in germinal epithelium and vacuolated spermatognial cells. Depletion of Leydig cells and degeneration of Sertoli cells were also noticed in the CP treated group. Our findings are in agreement with Amin et al. [71] who reported that degenerative changes in CP treated groups has an association with increase oxidative stress, DNA damage and decrease antioxidant defense system. The structural alterations observed in the current experiments may be corroborated with reductions in serum testosterone levels in respective groups. Giri and his colleagues revealed that treatment of $\mathrm{CP}$ reinforces ROS production inside the cell and hence sperms were in exposure to oxidative damage and Vitamin $\mathrm{C}$ ameliorates this damaging effect of CP [72]. Previous studies also reported that chemotherapy consequently decrease the number of Sertoli cells [73, 74]. In the present work, low serum levels of testosterone, LH and FSH and increase in $\mathrm{H}_{2} \mathrm{O}_{2}$ and other oxidative markers in the testicular tissue corroborate with the observations of structural alterations and inhibition of the spermatogenesis in $\mathrm{CP}$ injected groups. Overall, it was observed that considerable germ cell damage instigated by anticancer drugs is proceeded by a sharp degenerations in testicular histological parameters [75]. Treatments with AHE significantly protect the testicular morphology; pre-treatment outcomes in the marked prevention of CP induced toxicity. The mechanism of AHE to protect testicular damage is through its antioxidant and free radical scavenging potential due to the presence of polyphenols and flavonoids [24, 25].

Comet assay was performed to estimate the DNA damages incited with CP generated ROS in testicular tissue. In current study significant increase in tail moment, comet length, \% DNA in the tail was recorded in CP group. The oral dose significantly ameliorates the altered comet parameters and the DNA protective effect was more pronounced in $\mathrm{AHE}+\mathrm{CP}$ group supporting the previous observations that AHE has preventive potential. Similar results were reported by Sahreen et al. [12] where genotoxicity was induced by $\mathrm{CCl}_{4}$ in renal tissues and ameliorated with extract of Carissa opaca fruit. Our results suggested that A. hydaspica is a worthy candidate to inhibit the DNA damage in testicular tissues.

Figure 6 summarizes the possible mechanism of AHE protective effect against $\mathrm{CP}$ mediated reproductive toxicity. The treatment of AHE for CP induced testicular toxicity has efficiently ameliorated the altered level of antioxidant enzymes, biochemical markers, DNA damages and histoarchitecture of testis in a rat model. Similarly the derailed level of hormones in the serum was reverted towards the level of control with AHE in the $\mathrm{CP}$ treated rats. The protective and curative activities manifested by the AHE in this investigation are encouraging as the more efficacious therapeutics is needed to have multitude role in the oxidative stress related disorders. These studies would be helpful in the designing of biologically active drugs having minimum side effects and cost-effective.

\section{Conclusion}

In conclusion, the current investigation ratifies that reproductive toxicity induced by $\mathrm{CP}$ is related to increased oxidative stress. AHE as a potential antioxidant might be utilized in conjuction with or before chemotherapeutic drug administration to avoid the associated side effects. Results clearly augment the defensive mechanism of AHE against oxidative stress induced by $\mathrm{CP}$ and provide confirmation about its therapeutic use in reproductive abnormalities.

\section{Abbriviations \\ AHE: A. hydaspica ethyl acetate extract:; CP: Cisplatin; FSH: Follicle stimulating hormone; GnRH: Gonadotrophin releasing hormone; Gpx: Glutathione peroxidase; GSH: Reduce glutathione; HPA: Hypothalamo-pituitary axis; LH: Luteinizing hormone; $\mathrm{O}_{2} \cdot-$ : Superoxide; POD: Peroxidase; \\ SOD: Superoxide dismutase; TBARs: Thiobarbituric acid reactive substances}

\section{Acknowledgements}

We acknowledge Higher Education Commission (HEC) of Pakistan for awarding indigenous scholarship and IRSP scholarship for University of Minnesota, USA to the first author. Furthermore we are grateful to the Deanship of Scientific Research at King Saud University for its funding of this research through Research Group Project number 193.

\section{Funding}

The project was partially funded by the Higher Education Commission (HEC) of Pakistan by awarding indigenous scholarship to the first author. We are grateful to the Deanship of Scientific Research at King Saud University for its funding of this research through Research Group Project number 193. The funding body had no role in the design of the study and collection, analysis, and interpretation of data and in writing the manuscript.

Availability of data and materials

All the data is contained in the manuscript.

Authors' contributions

TA made significant contributions to conception, design, experimentation, acquisition and interpretation of data and writing of manuscript. SR, MRK, 
AHA and AA made substantial contribution in interpretation of data and revising the manuscript for intellectual content. All authors read and approved the final manuscript.

\section{Ethics approval and consent to participate}

All experimental procedures involving animals were conducted in accordance with the guidelines of the National Institutes of Health (NIH guidelines). The experimental protocol for the use of animal was approved (Bch\#0256) by the ethical board of Quaid-i-Azam University, Islamabad Pakistan.

\section{Competing interests}

The authors declare that they have no competing interest.

\section{Publisher's Note}

Springer Nature remains neutral with regard to jurisdictional claims in published maps and institutional affiliations.

\section{Author details}

'Department of Biochemistry, Quaid-i-Azam University, Islamabad, Pakistan. ${ }^{2}$ Department of Animal Sciences, Quaid-i-Azam University, Islamabad, Pakistan. ${ }^{3}$ Department of Community Health Sciences, College of Applied Medical Sciences, King Saud University, Riyadh, KSA, Saudi Arabia.

\section{Received: 31 December 2016 Accepted: 8 December 2017}

Published online: 21 December 2017

\section{References}

1. Yildirim NC, Kandemir FM, Benzer F. Beneficial effects of grape seed extract against cisplatin-induced testiculer damage in rabbits. Dig J Nanomater Biostruct. 2011;6(1):155-9.

2. SCHILSKY RL, LEWIS BJ, SHERINS RJ, YOUNG RC. Gonadal dysfunction in patients receiving chemotherapy for cancer. Ann Intern Med. 1980;93(1_Part_1):109-14.

3. Loehrer PJ, LH EINHORN. Cisplatin. Ann Intern Med. 1984:100(5):704-13.

4. Türk $G$, Ateşşahin $A$, Sönmez $M$, Çeribaşi $A O$, Yüce $A$. Improvement of cisplatin-induced injuries to sperm quality, the oxidant-antioxidant system and the histologic structure of the rat testis by ellagic acid. Fertil Steril. 2008;89(5):1474-81.

5. Huleihel M, Lunenfeld E. Regulation of spermatogenesis by paracrine/ autocrine testicular factors. Asian J Androl. 2004;6(3):259-68.

6. Yamaguchi K, Ishikawa T, Kondo Y, Fujisawa M. Cisplatin regulates Sertol cell expression of transferrin and interleukins. Mol Cell Endocrinol. 2008; 283(1):68-75.

7. Adler I-D, El-Tarras A. Clastogenic effects of cis-diamminedichloroplatinum: I. Induction of chromosomal aberrations in somatic and germinal cells of mice. Mutat Res. 1989;211(1):131-7.

8. Meistrich ML, Finch M, da Cunha MF, Hacker U, WW A. Damaging effects of fourteen chemotherapeutic drugs on mouse testis cells. Cancer Res. 1982; 42(1):122-31.

9. Seaman F, Sawhney P, Giammona C, Richburg J. Cisplatin-induced pulse of germ cell apoptosis precedes long-term elevated apoptotic rates in C57/BL/ 6 mouse testis. Apoptosis. 2003;8(1):101-8.

10. Lirdi LC, Stumpp T, Sasso-Cerri E, Miraglia SM. Amifostine protective effect on cisplatin-treated rat testis. Anat Rec. 2008;291(7):797-808.

11. Farias-Silva E, Cola M, Calvo TR, Barbastefano V, Ferreira AL, Michelatto DDP, de Almeida ACA, Hiruma-Lima CA, Vilegas W, Brito ARS. Antioxidant activity of indigo and its preventive effect against ethanol-induced DNA damage in rat gastric mucosa. Planta Med. 2007:73(12):1241-6.

12. Antunes F, Cadenas E. Cellular titration of apoptosis with steady state concentrations of $\mathrm{H} 2 \mathrm{O}$ 2: submicromolar levels of $\mathrm{H} 2 \mathrm{O} 2$ induce apoptosis through Fenton chemistry independent of the cellular thiol state. Free Radic Biol Med. 2001;30(9):1008-18.

13. Chirino Yl, Pedraza-Chaverri J. Role of oxidative and nitrosative stress in cisplatin-induced nephrotoxicity. Exp Toxicol Pathol. 2009;61(3):223-42.

14. Nejad D, Rad J, Roshankar L, Karimipor M, Ghanbari A, Aazami A, Valilou M. A study on the effect of thiotepa on mice spermatogenesis using light and electronic microscope. Pak J Biol Sci. 2008;11(15):1929-34.

15. Ali BH, Al Moundhri MS. Agents ameliorating or augmenting the nephrotoxicity of cisplatin and other platinum compounds: a review of some recent research. Food Chem Toxicol. 2006;44(8):1173-83.
16. Yagmurca M, Bas O, Mollaoglu H, Sahin O, Nacar A, Karaman O, Songur A. Protective effects of erdosteine on doxorubicin-induced hepatotoxicity in rats. Arch Med Res. 2007;38(4):380-5.

17. Yousef M, Saad A, El-Shennawy L. Protective effect of grape seed proanthocyanidin extract against oxidative stress induced by cisplatin in rats. Food Chem Toxicol. 2009;47(6):1176-83.

18. Shah NA, Khan MR, Naz K, khan MA. antioxidant potential, DNA protection, and HPLC-DAD analysis of neglected medicinal Jurinea dolomiaea roots. Biomed Res Int. 2014;2014

19. Hemalswarya S, Doble M. Potential synergism of natural products in the treatment of cancer. Phytother Res. 2006;20(4):239-49.

20. Seigler DS. Phytochemistry of Acacia-Sensu Lato. Biochem Syst Ecol. 2003; 31(8):845-73.

21. Sakthivel K, Kannan N, Angeline A, Guruvayoorappan C. Anticancer activity of Acacia Nilotica (L.) wild. Ex. Delile Subsp. Indica against Dalton's ascitic lymphoma induced solid and ascitic tumor model. Asian Pac J Cancer Prev. 2012;13(8):3989-95.

22. Duarte MR, Wolf $\mathrm{S}$. Anatomical characters of the phyllode and stem of Acacia podalyriifolia A. Cunn. ex G. Don (Fabaceae). Rev Bras. 2005:15(1):71-6.

23. Chakrabarty T, Gangopadhyay M. The genus acacia P. Miller (Leguminosae: Mimosoideae) in India. J Econ Taxon Bot. 1996;20(3):599-633.

24. Afsar T, Khan MR, Razak S, Ullah S, Mirza B. Antipyretic, anti-inflammatory and analgesic activity of Acacia Hydaspica R. Parker and its phytochemical analysis. BMC Complement Altern Med. 2015;15(1):136.

25. Afsar T, Trembley JH, Salomon CE, Razak S, Khan MR, Ahmed K. Growth inhibition and apoptosis in cancer cells induced by polyphenolic compounds of Acacia Hydaspica: involvement of multiple signal transduction pathways. Sci Rep. 2016:6:23077.

26. Afsar T, Razak S, Khan MR, Mawash S, Almajwal A, Shabir M, Haq IU Evaluation of antioxidant, anti-hemolytic and anticancer activity of various solvent extracts of Acacia Hydaspica R. Parker aerial parts. BMC Complement Altern Med. 2016;16(1):258.

27. Ojha S, Al Taee H, Goyal S, Mahajan UB, Patil CR, Arya D, Rajesh M. Cardioprotective potentials of plant-derived small molecules against doxorubicin associated cardiotoxicity.Oxid Med Cell Longev 2016:2016:5724973.

28. Fouad AA, Qutub HO, Fouad AEA, Audeh AM, Al-Melhim WN. Epigallocatechin-3gallate counters cisplatin toxicity of rat testes. Pharm Biol. 2017:55(1):1710-4.

29. Chtourou Y, Boudawara T, Zeghal N. Protective role of silymarin against manganese-induced nephrotoxicity and oxidative stress in rat. Environ Toxicol. 2014;29(10):1147-54.

30. Razavi BM, Karimi G. Protective effect of silymarin against chemical-induced cardiotoxicity. Iranian journal of basic medical sciences. 2016;19(9):916.

31. Kranti V, Mahesh V, Srinivas P, Ganesh Y, Godwin A, Lahkar M. Evaluation of the protective effect of silymarin on doxorubicin induced chronic testicular toxicity in rats. Int J Pharm Bio Sci. 2013;4(1):473-84.

32. Afsar T, Khan MR, Razak S, Ullah S, Mirza B. Antipyretic, anti-inflammatory and analgesic activity of Acacia Hydaspica R. Parker and its phytochemical analysis. BMC Complement Altern Med. 2015;15(1):1

33. Guideline 00. 425: acute oral toxicity—up-and-down procedure. Paris: OECD Guidelines for the Testing of Chemicals Organization for Economic Cooperation and Development; 2001.

34. Turner P, Granville-Grossman K, Smart J. Effect of adrenergic receptor blockade on the tachycardia of thyrotoxicosis and anxiety state. Lancet. 1965;286(7426):1316-8.

35. Guideline OO. 425: acute oral toxicity-up-and-down procedure. OECD Guidelines for the Testing of Chemicals. 2001:2:12-6.

36. Irwin S. Comprehensive observational assessment: la. A systematic, quantitative procedure for assessing the behavioral and physiologic state of the mouse. Psychopharmacology. 1968;13(3):222-57.

37. Mensah A, Mireku E, Mensah M, Amponsah I. Some neurological effects of the ethanolic stem bark extract of Cussonia bancoensis Aubrev and Pellgr (Araliaceae). Journal of Pharmacognosy and Phytochemistry. 2014; 2(6):101-6.

38. Nasr AY, Saleh HA. Aged garlic extract protects against oxidative stress and renal changes in cisplatin-treated adult male rats. Cancer Cell Int. 2014:14(1):92.

39. Mohamed MM. Garlic powder attenuates acrylamide-induced oxidative damage in multiple organs in rat. J Appl Sci Res. 2012;8(1):168-73.

40. Chance B, Maehly A: [136] assay of catalases and peroxidases. 1955

41. Kakkar P, Das B, Viswanathan P. A modified spectrophotometric assay of superoxide dismutase. Indian J Biochem Biophys. 1984;21(2):130-2. 
42. Benson AM, Hunkeler MJ, Talalay P. Increase of NAD (P) H: quinone reductase by dietary antioxidants: possible role in protection against carcinogenesis and toxicity. Proc Natl Acad Sci. 1980;77(9):5216-20.

43. Jollow D, Mitchell J, Zampaglione N, Gillette J. Bromobenzene-induced liver necrosis. Protective role of glutathione and evidence for 3, 4-bromobenzene oxide as the hepatotoxic metabolite. Pharmacology. 1974;11(3):151-69.

44. Habig WH, Pabst MJ, Jakoby WB. Glutathione S-Transferases the first enzymatic step in mercapturic acid formation. J Biol Chem. 1974;249(22):7130-9.

45. Carlberg I, Mannervik B. Purification and characterization of the flavoenzyme glutathione reductase from rat liver. J Biol Chem. 1975;250(14):5475-80.

46. Mohandas J, Marshall JJ, Duggin GG, Horvath JS, Tiller DJ. Differential distribution of glutathione and glutathione-related enzymes in rabbit kidney: possible implications in analgesic nephropathy. Biochem Pharmacol. 1984;33(11):1801-7.

47. Orlowski M, Sessa G, Green JP. y-Glutamyl transpeptidase in brain capillaries: possible site of a blood-brain barrier for amino acids. Science. 1974;184(4132):66-8.

48. Pick E, Mizel D. Rapid microassays for the measurement of superoxide and hydrogen peroxide production by macrophages in culture using an automatic enzyme immunoassay reader. J Immunol Methods. 1981;46(2):211-26.

49. Green LC, Wagner DA, Glogowski J, Skipper PL, Wishnok JS, Tannenbaum SR. Analysis of nitrate, nitrite, and [15 N] nitrate in biological fluids. Anal Biochem. 1982;126(1):131-8.

50. lqbal S, Bhanger M, Anwar F. Antioxidant properties and components of some commercially available varieties of rice bran in Pakistan. Food Chem. 2005;93(2):265-72.

51. Islam MN, Zhu ZB, Aoyama M, Sugita S. Histological and morphometric analyses of seasonal testicular variations in the jungle crow (Corvus Macrorhynchos). Anat Sci Int. 2010;85(3):121-9.

52. Jensen EC. Quantitative analysis of histological staining and fluorescence using ImageJ. Anat Rec. 2013;296(3):378-81.

53. Sawhney P, Giammona CJ, Meistrich ML, Richburg JH. Cisplatin-induced long-term failure of spermatogenesis in adult (57/BI/6J mice. J Androl. 2005;26(1):136-45.

54. Rezvanfar MA, Rezvanfar MA, Shahverdi AR, Ahmadi A, Baeeri M Mohammadirad A, Abdollahi M. Protection of cisplatin-induced spermatotoxicity, DNA damage and chromatin abnormality by selenium nano-particles. Toxicol Appl Pharmacol. 2013;266(3):356-65.

55. Aminsharifi A, Shakeri S, Ariafar A, Moeinjahromi B, Kumar PV, Karbalaeedoost S. Preventive role of exogenous testosterone on cisplatininduced gonadal toxicity: an experimental placebo-controlled prospective trial. Fertil Steril. 2010;93(5):1388-93.

56. Türk $G$, Ateşşahin A, Sönmez M, Yüce A, Çeribaşi AO. Lycopene protects against cyclosporine $A$-induced testicular toxicity in rats. Theriogenology. 2007;67(4):778-85.

57. Latif R, Lodhi GM, Aslam M. Effects of amlodipine on serum testosterone, testicular weight and gonado-somatic index in adult rats. J Ayub Med Coll Abbottabad. 2008;20(4):8-10.

58. Azu OO, Duru Fl, Osinubi AA, Noronha CC, Elesha SO, Okanlawon AO. Protective agent, Kigelia Africana fruit extract, against cisplatin-induced kidney oxidant injury in Sprague-Dawley rats. Asian J Pharma Clin Res. 2010;3(2):84-8.

59. Manna P, Sinha M, Sil PC. Aqueous extract of Terminalia Arjuna prevents carbon tetrachloride induced hepatic and renal disorders. BMC Complement Altern Med. 2006;6(1):1.

60. MD MAINES, PM SLUSS, ISCAN M. Cis-platinum-mediated decrease in serum testosterone is associated with depression of luteinizing hormone receptors and cytochrome P-450scc in rat testis*. Endocrinology. 1990;126(5):2398-406.

61. García MMS, Acquier A, Suarez G, Gomez NV, Gorostizaga A, Mendez CF, Paz C. Cisplatin inhibits testosterone synthesis by a mechanism that includes the action of reactive oxygen species (ROS) at the level of P450scc. Chem Biol Interact. 2012;199(3):185-91.

62. Ilbey YO, Ozbek E, Cekmen M, Simsek A, Otunctemur A, Somay A. Protective effect of curcumin in cisplatin-induced oxidative injury in rat testis: mitogen-activated protein kinase and nuclear factor-kappa B signaling pathways. Hum Reprod. 2009;24(7):1717-25.

63. Brilhante O, Stumpp T, Miraglia S. Long-term testicular toxicity caused by doxorubicin treatment during pre-pubertal phase. Int J Med Sci. 2011;3(2):52-60.

64. Hozayen WG. Effect of hesperidin and rutin on doxorubicin induced testicular toxicity in male rats. Int J Food Nutr Sci. 2012;1:31-42.

65. Chapman R, Rees L, Sutcliffe S, Edwards C, Malpas J. Cyclical combination chemotherapy and gonadal function: retrospective study in males. Lancet. 1979;313(8111):285-9.
66. Patil $L$, Balaraman R. Effect of melatonin on doxorubicin induced testicular damage in rats. Int J PharmTech Res. 2009;1(3):879-4.

67. Acar N, Berdeaux O, Grégoire S, Cabaret S, Martine L, Gain P, Thuret G, Creuzot-Garcher CP, Bron AM, Bretillon L. Lipid composition of the human eye: are red blood cells a good mirror of retinal and optic nerve fatty acids? PLoS One. 2012;7(4):e35102.

68. Khaki A, Fathiazad F, Nouri M, Khaki AA, Ozanci CC, Ghafari-Novin M, Hamadeh $M$. The effects of ginger on spermatogenesis and sperm parameters of rat. Iranian Journal of Reproductive Medicine. 2009;7(1):7-12.

69. Sharma RK, Agarwal A. Role of reactive oxygen species in male infertility. Urology. 1996;48(6):835-50.

70. Sridevi T. Effect of doxorubicin on the biochemical activities of the male reproductive system of white mice-Mus Musculus. Indian Journal of Science and Technology. 2011:4(12):1715-20.

71. Amin A, Abraham C, Hamza AA, Abdalla ZA, Al-Shamsi SB, Harethi SS, Daoud S. A standardized extract of Ginkgo Biloba neutralizes cisplatinmediated reproductive toxicity in rats. Biomed Res Int. 2012;2012.

72. Giri A, Khynriam D, Prasad SB, Vitamin C. Mediated protection on cisplatin induced mutagenicity in mice. Mutat Res. 1998;421(2):139-48.

73. Boujrad N, Reviers M, Kamtchouing P, Perreau C, Carreau S. Evolution of somatic and germ cell populations after busulfan treatment in utero or neonatal cryptorchidism in the rat. Andrologia. 1995:27(4):223-8.

74. Ghosh S, Bartke A, Grasso P, Reichert L Jr, Russell LD. Structural manifestations of the rat Sertoli cell to hypophysectomy: a correlative morphometric and endocrine study. Endocrinology. 1992;131(1):485-97.

75. França LR, Godinho CL. Testis morphometry, seminiferous epithelium cycle length, and daily sperm production in domestic cats (Felis Catus). Biol Reprod. 2003;68(5):1554-61.

\section{Submit your next manuscript to BioMed Central and we will help you at every step:}

- We accept pre-submission inquiries

- Our selector tool helps you to find the most relevant journal

- We provide round the clock customer support

- Convenient online submission

- Thorough peer review

- Inclusion in PubMed and all major indexing services

- Maximum visibility for your research

Submit your manuscript at www.biomedcentral.com/submit
Biomed Central 